\title{
A perfect gift
}

Late in 1902 there was published in London a little book in dark blue wrappers entitled From the Abyss, and sub-titled of its Inhabitants. Instead of giving the author's name, the title page simply lists the book as "by one of them". Priced at one shilling net, it must have sold reasonably well, for a new edition was called for in 1911 .

In January 1903 the author of the book presented a copy to G.M. Trevelyan, then a young Fellow of Trinity College, Cambridge, and again he prefers anonymity, signing as simply "From the author". of course Trevelyan knew him, for Charles Frederick Gurney Masterman (1874-1927) had been a year ahead of him at Cambridge. Trevelyan thought well enough of the book to recommend it to Bertrand Russel1, whom he had met early in his Cambridge days and who was already an Apostle when Trevelyan was elected to membership in that extraordinary Society. Indeed, Trevelyan probably loaned Russell his copy of the book, but however it was, Russell had read the book by 25 January, for on that day he wrote Trevelyan a letter about it. Of the many letters Russell wrote to Trevelyan this is the only one now known, and it is a gem.

14, CHEYNE WALK, CHELSEA, S.W.

January 25,1903

Dear George

I have read Masterman, and on the whole I think it a great book. There are certain trivial literary faults, and it would have been better not to bring in God at the end; but he gives most impressively the picture of plodding, careful lives, without hope, without much fear, toiling slowly to the grave. By his self-restraint and avoidance of over-statement (both of which strike me as yery admirable) he has avoided the literary failure which usually mars such writing, and has written in a way worthy of his subject. The intolerable irony and emptiness of it all is most terrible - the

hooligans are really a bright spot in the picture. It is very strange, and still unintelligible to me, that such a picture should have beauty, but so it is. What an aichemist the mind is, when it contains the potent ingredients of deep and true feeling. Good writing, in prose especially, seems to me often a direct outcome of a good 1ife; indeed many great themes, such as Masterman's, have only failed to be adequately treated because men of leisure have not been willing to 
inflict upon themselves the knowledge that he has harboured. God knows what is to become of this nation! or indeed of the world, for the economic man cannot be isolated, but must spread his infection broadcast through the continents. Is it a dying world? Are we the last inheritors of al1 the treasure of the ages? Surely not: some way must be found. But for my part I see none.

Yours ever affectionately Bertrand Russe11.

The date of this letter is significant. From a diary he kept at the time we know that it was written during the period he was writing "The Free Man's Worship", which it resembles both in mood and literary style. An entry dated 27 January 1903, two days after the date of the letter, notes that the essay is finished. On that day too he records his displeasure with his wife's behaviour toward Cambridge people, and goes on to write that he is "unhappy beyond what I know how to bear". "Happiness is gone for ever, my work is second-rate, and all I care for is gone or going." One can hardiy imagine a more congenial state of mind in which to read Masterman's gloomy little book.

From the Abyss has as its theme what we now call "urban sprawl". Masterman's concern is with both its material and spiritual manifestations. London at the turn of the century was pouring out in all directions. "Block-busting" was as much practiced then as it is now: an "ancient house or we17-wooded estate" in a tranquil 1 suburb is abruptly and rudely replaced by "a little packed maze of little packed houses all leaning up against each other lest they shourd fall down, cut into cubes, with tiny backyards in which a woman can just turn round". (pp. 42,43) The rest of the suburb is soon transformed to match, much as if it were a super-saturated solution in to which a crystal had been thrown. The quality of material life is matched by the quality of the spiritual life of the inhabitants of these instant ghettos. Spending their leisure time in "gin palaces" was the highest cultural aim of which they were capable, although Masterman suggests that if they were not so overworked better activities might have more appeal. His complaints are familiar ones: the business of the city holds a fatal attraction to people whose nature it warps through its use of them until they become little more than automata trudging to their (usually early) deaths.

Every single person, he is arguing, would be much better off if there were far fewer human beings.

Since we know Russell was already intensely unhappy when he read the book and was disposed to think the worst of everything, the tone of his letter to Trevelyan is not surprising. No doubt he detected, or thought he detected, a kindred spirit in Masterman. They had never met, although Masterman had been only two years behind him at Cambridge, so Trevelyan arranged a luncheon for the three of them for 11 February 1903. Russell's diary entry is terse: "Lunched with Masterman and George Trevelyan. Masterman was too Christian for me, and I liked him less than I had expected." There is no record of any other contact between them. Masterman went on to become a Liberal politican, was several times elected to Parliament, and was a member of the Cabinet which declared war in August of 1914. "He was proud, as he wrote afterwards in a letter to the prime minister, to be associated with a government which had faced the situation and had chosen war as the only alternative to dishonour." (D.N.B. 1922-30) Russell would have been appalled.

On the evening of 3 May 1974 my colleagues and friends presented me with the copy of the book about which I have been writing. Russell's handwritten letter to Trevelyan was tucked inside it. The occasion was my retirement, after a five-year term, as Chairman of the Department of Philosophy. The importance of the letter made me wish to share it with readers of Russell, so I suggested to the editor, through whose kind and generous efforts the book and letter had been secured, that I write it up for him. I am very happy to share what was, for me, a perfect gift.

Department of Philosophy University of Toronto
John G. Slater 